\title{
On Literal Translation of English Idioms
}

\author{
Linli Chen \\ Yunnan RTV University \\ 113 Xue Fu Road, Kunming 650223, China \\ Tel: 86-871-287-1332Ｅ-mail: cllzyq@sina.com
}

\begin{abstract}
There are six translation tactics in translating English idioms into Chinese: literal translation, compensatory translation, free translation, explanational translation, borrowing, integrated approach. Each tactics should be reasonably employed in the process of translating, so as to keep the flavor of the original English idioms as well as to cater for the Chinese readers. In this paper, one of the tactics: literal translation will be discussed, which is the most commonly used tactics in translating English idioms.
\end{abstract}

Keywords: English idioms, Translation tactics, Literal translation

Every language has its own idioms, a special kind of set expressions that have developed within a language. English and Chinese are abundant in idioms. As an important part of the general vocabulary of every language, idioms are the gems of a language, which have been described as the crystallization of human wit and wisdom.

Webster's New World Dictionary of the American English (1988) defines "idiom" as: 1) the language proper or peculiar to a people or to a district, community or class; the syntactical, grammatical or structural form peculiar to a language; 2 ) an expression established in the usage of a language that is peculiar to itself either in grammatical construction or in having a meaning that cannot be derived as a whole from the conjoined meanings of its elements; 3) style or form of artistic expression (as in painting, writing, composing) that is characteristic especially of an individual, a period or movement, or a medium or instrument.

We may conclude from the definitions that an idiom is an expression whose meaning is not compositional, and does not follow from the meaning of the individual words which make up of it. It is "an accepted phrase, construction, or expression contrary to the usual patterns of the language or having a meaning different from the language or having a meaning different from the literal." (Webster's New World Dictionary of the American language, 2nd college edition, 1972)

In some senses, idioms are the reflection of the environment, life, historical culture, etc. of the native speakers and are closely associated with their innermost spirit and feelings. They are commonly used in all types of language, informal and formal, spoken and written.

As idioms are important part of languages, understanding of a language requires understanding of its idioms and the tactics for idiom translation. Translation is no easy job, especially the translation of idioms because idioms are the most difficult part to render. In general, three ways are possible in translating idioms, to name only a few : (1) to translate the idiom literally ; (2) to render the sense of the idiom ; or (3) to use an equivalent idiom in the receptor language. To make people better understand idioms, in this paper, according to Nida's "dynamic equivalence" translating theory, literal translation method of English idioms is to be discussed because it is the most commonly used tactics in translating idioms as well as a means of culture exchange.

\section{Literal Translation}

Literal translation is usually employed in the complete representation of the original when the original almost accords with the target language in the form of vocabulary, grammatical structure and rhetorical device, which means literal translation is a way by which the rhetoric, national and regional characteristics are kept in the target language. The aim of literal translation is to preserve the national flavor of the source language idioms, while not transgressing the linguistic principles of the target language. Translators should make every endeavor to retain the figurative image, rhetorical devices and the national characteristics of the original idioms. In this way, the meaning and form of the source language are unchanged. Sometimes, equivalent translation can be found, but mostly only similar ones. As Nida says, "Finding satisfactory equivalents for idioms is one of the most difficult aspects of translating." (Nida, E.A., 2001: 28) Many English idioms can be translated in a literal way, for instance: "A wolf in sheep's clothing" is translated literally into "Pi Zhe Yang Pi De Lang"; "To pull chestnut out of the fire" is translated literally into "Huo Zhong Qu Li" and "To be led by the nose" into "Bei Qian Zhe Bizi Zou". As to these idioms, in the process of across-cultural communication, 
we have absorbed a lot of them into our language.

\section{Literal Translation can produce equivalent effect}

Language universal and cultural similarities are two factors in the objective world which enable across-cultural communications. People of different languages may share the same feelings, emotions and ways of thinking, because people of different nations experience the same things in the unique nature. Misunderstanding may not be aroused in translating some SL (Source Language) text literally into the TL (Target Language), when the translated text have the same literal meaning or figurative meaning and implicated meaning with the SL text. Therefore, literal translation method can be employed.

In terms of idiom translation, some idioms could be translated literally. Literal translation can keep the original form and images of English idioms without causing confusion in meaning. For example, "Break the record" is translated literally into "Da Po Ji Lu"; What's more, literal translation transfers the original cultural information effectively and conveys the implicated meaning without misunderstandings aroused and narrows the gaps between two languages, and at the same time, interests in reading can be greatly enhanced. For instance, "A rolling stone gathers no moss" is translated literally into "Gun Shi Bu Sheng Tai", it implies that a person who is constantly moving and changing from one place or occupation to another will never gain a steady, established position. And "Packed like sardines" is translated literally into "Ji Dei Xiang Guan Tou Sha Ding Yu", it is a preferred version of translation because it fulfills the function of communicative translation yet retains the original flavor of the source idiom, when the implicated meaning of the idioms can be easily inferred, the idioms can be understood literally by the reader. In this case, these kinds of idioms can be rendered through the employment of literal translation. The most important point of literal translation lies in the function of keeping the full flavor of English idioms.

Let's take the following sentence as an example, "At present the superpowers are armed to the teeth with nuclear weapons, placing the people of the whole world under their nuclear threat."

A. Mù Qián, Chāo Jí Dà Guó Hé Wǔ Qì Wǔ Zhuāng Dào Le Yá Chǐ, Bă Quán Shì Jiè Rén Mín Dōu ZhìYú Tā Men De Wēi Xié Zhī Xià.

B. Mù Qián, Chāo Jí Dà Guó Yòng Hé Wǔ Qì Quán Fù Wǔ Zhuāng, Bă Quán Shì Jiè Rén Mín Dōu ZhìYu Tā Men De Wēi Xié Zhī Xià.

Obviously A fits the original sentence better than B because the English idiom "armed to the teeth" and its Chinese meaning "Wu Zhuang Dao Le Ya Chi" are perfectly equivalent. A employs literal translation, which keeps the original form and images and causes no confusion at all, at the same time, vivifies the expression, and above everything else, keeps the full flavor of this idiom. On the contrary, B, a free version, with the loss of cultural meaning, violates the "faithfulness" of translation criteria. Here are some more examples with literal translation from English into Chinese with Nida's "dynamic equivalence" theory employed:

Turn a deaf ear (Zhi Ruo Wang Wen)

To be on the thin ice (Ru Lü Bo Bing)

a gentleman's agreement (Jun Zi Xie Ding)

It is obvious that all the above idioms are rendered into Chinese by employing literal translation, which keeps the original form and images, at the same time, vivifies the expression, and above everything else, keeps the full flavor of the idioms. The Chinese renditions of these English idioms are so well-selected that the idioms and their Chinese counterparts: "Zhi Ruo Wang Wen", "Ru Lü Bo Bing", and "Jun Zi Xie Ding" almost contain the same messages and adopt the same rhetorical devices. Similarly, "Barking dogs do not bite" can be translated literally into "Fei Gou Bu Yao Ren", "All roads lead to Rome" is "Tiao Tiao Da Dao Tong Luo Ma" and "What's done is done and can't be undone" is literally translated into "Mu Yi Cheng Zhou, Fu Shui Nan Shou", in translating them in this way, wisdom of the people is conveyed figuratively to different readers in much the same way through different languages.

To produce equivalent effect on the minds of the readers, the same or similar metaphor is used to render them into corresponding Chinese for the purpose of faithfully and vividly reproducing both the original message and flavor of the original. Thus, information concerning wisdom and suitable ways of behaving from those English-speaking countries can be passed on to us Chinese vividly and correctly.

\section{Conclusion}

Examples of literal rendering in the translation of English idioms are numerous. Indeed, literal translation should claim top priority in translation, because translation is a means of culture exchange. During the process of translating, a translator should respect both the source language and the target language and their respective culture. He should bear in mind the responsibility for introducing cultural heritage to target language readers.

Language cannot exist without culture as its component. As part of language, idioms are characterized by their richness 
and vividness in their concise expressions. In a broad sense, human beings share common culture and cultural similarities that are the overlaps of cultural features between languages. When idioms of the source language are similar to those of the target language in terms of choice of words, collocation and social meanings, according to Nida's Dynamic Equivalence theory, translation becomes easy because of the positive influence of cultural similarities. In this sense, literal translation should claim top priority in translation. The main cultural differences between Chinese and English idioms lie not only in the language expression and ways of vocabulary, grammar and rhetoric devices, but also in their different cultural backgrounds, because Chinese and English idioms originate from different cultures. Thus, in translation of idioms, much attention should be paid to the dissimilarities of cultures as well as languages themselves.

\section{References}

Bosong Chen. (1986). An Outline of English Idioms. Wuhan: Hubei Education Press.

Nida, Eugene A. (1986). From one Language to Another. Shanghai: Shanghai Foreign Language Education Press.

Nida, Eugene A. (2001). Language, Culture and Translating. Shanghai: Shanghai Foreign Language Education Press.

Nida, Eugene A. \& C. R. Taber (1969). The Theory and Practice of Translation. Leiden: Brill.

Webster's New World Dictionary of the American language, $2^{\text {nd }}$ college ed.(1972). New York: Webster's New World. Webster's New World Dictionary of the American English, $3^{\text {rd }}$ college ed.(1988).New York: Webster's New World.

Fumin Yu \& Shanlian Guo. (1999). A Comparative Study of English and Chinese Idioms. Shanghai: Shanghai Jiao Tong University Press. 